DOI: $10.36067 /$ jbis.v2i2.72

ISSN: 2685-2543

\title{
Pengujian faktor anteseden pada loyalitas pengguna internet banking
}

\author{
${ }^{1)}$ Agustinus Widyartono \\ widyartono@ukmc.ac.id \\ ${ }^{2)}$ Andreas Sardjono \\ andreas@ukmc.ac.id \\ ${ }^{1,2)}$ Program Studi Manajemen, Universitas Katolik Musi Charitas Palembang
}

\begin{abstract}
This study aims to prove the influence of shared value and communication carried out by banking industry actors on the internet banking service to customer loyalty by trust mediation. The survey that will be conducted in this study includes the users of internet banking in the city of Palembang. Data collection techniques were carried out by distributing questionnaires to 100 users of internet banking. The method that will be used in this research is to use path analysis. This research proves that the value shared and communication significantly influence trust. This study also proves that trust is a variable that mediates the effect of shared values on loyalty. The communication factor in which the internet banking application is used is able to convey clear information to customers and this will increase customer confidence in the application. Besides that, customers also have and get value for internet banking applications to make customers more confident or trust in the application.
\end{abstract}

Keywords: shared values; communication; trust; loyalty; internet banking

\section{Pendahuluan}

Asosiasi Pengguna Jasa Internet Indonesia (APJIJ) tahun 2018 mengadakan survei tentang kecenderungan penggunaan internet di Indonesia. Hasil survei menunjukkan bahwa mayoritas pengguna internet di Indonesia masih menggunakan internet untuk mengakses layanan chating yaitu sebesar $89 \%$. Kemudian layanan yang diakses dengan menggunakan internet adalah akses ke sosial media untuk mengunggah foto diikuti dengan menjual atau membeli barang. Persentase layanan internet terendah dalam survey tersebut adalah untuk layanan perbankan.

Teknologi informasi telah mengubah cara operasi pada industri jasa seperti perhotelan, ritel, layanan kesehatan dan perbankan. Bank sudah mulai menggunakan internet sebagai saluran distribusi termasuk menambah kantor cabang. Revolusi internet dan difusi teknologi informasi telah menyebabkan perubahan besar dalam praktik dan perilaku pelanggan perbankan (nasabah). Nasabah lebih tertarik untuk menggunakan cara-cara yang lebih mudah, aman dan dapat diakses langsung untuk memenuhi kebutuhan perbankan. Saat ini nasabah lebih memilih transaksi online daripada harus datang langsung ke kantor cabang (Kaabachi et al., 2020).

Interaktivitas merupakan hal yang sangat penting saat ini karena merupakan website yang mampu menyampaikan informasi dengan komunikasi dua arah kepada nasabah. Beberapa penelitian menemukan bahwa interaktivitas sebuah website dapat membangun kepercayaa nasabah. Interaktivitas dari sebuah situs web berkontribusi untuk membangun kepercayaan konsumen dalam internet banking (Mann \& Sahni, 2011). Kepercayaan 
terhadap penyedia layanan bergantung pada apakah penyedia layanan itu memiliki kemampuan dan sumber daya untuk berinteraksi dengan konsumen (Nilashi et al., 2016). Informasi yang terperinci dan lengkap tentang produk dan layanan serta kebijakan privasi dan sistem keamanan merupakan faktor yang penting untuk membangun kepercayaan dalam e-commerce (Maadi et al., 2016). Seorang nasabah yang menggunakan internet banking akan memberikan nilai lebih atas layanan internet banking yang diberikan oleh pihak bank, sepert adanya keamanan pribadi, adanya ruang privasi, dan unsur etika. Atas dasar nilai lebih yang ada dalam layanan internet banking inilah maka nasabah akan mengembangkan kepercayaannya. Oleh karena itu, untuk meningkatkan kepercayaan konsumen dibutuhkan nilai lebih dalam suatu layanan perbankan. Nilai lebih ini akan terus dikomunikasikan atau dijelaskan oleh pihak bank sebagai wujud komitmen bank dalam menjaga dan memelihara privasi dan keamanan nasabah saat mengunjungi situs internet banking. Komunikasi yang dilakukan pihak bank secara terus menerus akan membuat nasabah percaya untuk menggunakan internet banking sebagai media transaksi. Suatu layanan internet banking yang memberikan keterbukaan informasi, kecepatan dalam merespon dan kualitas atas informasi akan memenuhi kebutuhan pengguna internet banking (Mukherjee \& Prithwiraj, 2003).

Perkembangan yang cepat pada internet banking, penting untuk dipahami apakah nasabah memiliki loyalitas dan kepercayaan. Untuk meningkatkan kepercayaan nasabah terhadap internet banking, sangat penting bagi pihak bank untuk mengetahui apakah komunikasi yang telah dilakukan dapat mempengaruhi kepercayaan nasabah dalam menggunakan fasilitas internet banking.

\section{Tinjauan Pustaka}

\subsection{Kepercayaan Konsumen}

Perbankan yang menggunakan layanan berbasis internet akan menanggung resiko karena pihak-pihak yang terlibat di dalam proses transaksi tidak berada di tempat yang sama. Melindungi rekening nasabah sangat bergantung pada kebijakan keamanan teknologi informasi yang dilaksanakan oleh sebuah bank. Ennew dan Sekhon dalam Kaabachi et al. (2020) mendefinisikan kepercayaan sebagai kesediaan individu untuk menerima kerentanan dengan alasan adanya harapan positif tentang niat atau perilaku orang lain dimana didalamnya ada ketergantungan dan risiko. Menurut Mayer dalam Vinayek \& Jindal (2011), kepercayaan merupakan keyakinan, harapan atau perasaan yang mengakar dalam kepribadian dan berasal dari perkembangan psikologis awal individu yang juga dikenal sebagai 'disposisi untuk percaya'. Pendapat lain yang dikemukakan oleh Morgan dalam Arcand et al., (2017), menjelaskan bahwa kepercayaan adalah keyakinan akan kehandalan dan integritas penyedia.

\subsection{Nilai yang Dibagi}

Punyatoya (2019) menyatakan bahwa nilai yang dibagi merupakan keyakinan umum mengenai perilaku, tujuan dan kebijakan, apa yang penting atau tidak penting, apa sesuai atau tidak pantas, dan benar atau salah. Nilai merupakan ukuran yang baik atas kesesuaian orang dan organisasi berdasarkan pandangan organisasi. Punyatoya (2019) melihat sejauh 
mana pelanggan merasa bahwa ia dan penyedia layanan berbagi kepentingan dan nilai-nilai bersama. Menurut Vinayek \& Jindal (2011), dimensi kualitas layanan untuk jasa perbankan yang unggul adalah efisiensi yang diikuti dengan kualitas informasi. Kedua dimensi ini memberikan dampak yang signifikan terhadap persepsi pelanggan atas kualitas layanan dan akan membangun preferensi yang baik dibandingkan dengan apa yang ditawarkan oleh pesaing. Pelanggan internet banking yang loyal cenderung menyebarkan berita positif pada halaman sosial media, sehingga memberikan hasil kesan yang positif kepada pelanggan lain (Kaur et al., 2012). Hipotesis dalam penelitian ini adalah sebagai berikut:

$H_{1}$ : Nilai yang dibagi berpengaruh positif dan signifikan terhadap kepercayaan pengguna internet banking.

\subsection{Komunikasi}

Interaksi digambarkan sebagai faktor antara pihak yang memiliki aksesibilitas dan merupakan alat untuk layanan pelanggan yang efisien pada sebuah situs web dimana komunikasi dua arah dengan pelanggan dapat difasilitasi (Chung et al., 2016). Dalam konteks internet banking nasabah akan mencari bantuan jika menghadapi kesulitan terutama, ketika penyedia internet banking memperbarui teknologi dan situs webnya, pelanggan cenderung mencari dukungan teknis dari penyedia internet banking (Thaichon et al., 2014). Kepercayaan terhadap penyedia layanan internet banking akan terjadi saat dukungan atas layanan online yang diberikan dapat ditunjukkan secara cepat untuk memberikan solusi atas pertanyaan nasabah tanpa adanya kerumitan (Quach et al., 2016). Informasi yang terperinci dan lengkap tentang perusahaan, tentang produk dan layanan serta kebijakan privasi dan sistem keamanan memiliki dampak yang signifikan dalam membangun kepercayaan dalam e-commerce (Maadi et al, 2016). Hipotesis dalam penelitian ini adalah sebagai berikut:

$\mathrm{H}_{2}$ : Komunikasi berpengaruh positif dan signifikan terhadap kepercayaan pengguna internet banking.

\subsection{Loyalitas}

Loyalitas merupakan istilah kuno yang secara tradisional telah digunakan untuk melukiskan kesetian dari pengabdian antusias kepada negara, cita-cita, atau individu (Lovelock \& Wright 1999). Dalam konteks bisnis Mukherjee \& Prithwiraj (2003) mendefinisikan loyalitas sebagai niat dari konsumen untuk kembali menggunakan internet banking berdasarkan pengalaman dan harapan dimasa lalu. Menjalankan sebuah bisnis diperlukan pendekatan yang berbasis pada hubungan agar diperoleh pemahaman tentang apa yang dibutuhkan dan diinginkan pelanggan serta memandang pelanggan sebagai asset jangka panjang (Barnes 2003).

Toufaily et al. (2013) mendefinisikan loyalitas konsumen online sebagai kesediaan pelanggan untuk mempertahankan stabilitas hubungan di masa depan dan untuk terlibat dalam perilaku kunjungan berulang dan atau pembelian produk atau layanan secara online dengan menggunakan situs web perusahaan sebagai alternatif pilihan pertama, dimana hal ini didasarkan pada keyakinan yang menguntungkan dan emosi yang positif. Konsumen umumnya peduli dengan transaksi perbankan yang tepat waktu dan bebas dari kesalahan. Pelanggan akan cenderung percaya atas layanan e-banking dan terus akan menggunakannya 
di masa depan jika layanan e-banking akurat dan tepat waktu (Shankar \& Jebarajakirthy 2019). Kepercayaan meningkatkan komitmen jangka panjang pelanggan terhadap penyedia layanan yang pada akhirnya akan meningkatkan loyalitas pelanggan (Shankar \& Jebarajakirthy 2019). Amin (2016) menyoroti bahwa kualitas situs web dalam e-banking sangat penting untuk peningkatan kualitas layanan karena dapat mempengaruhi kesetiaan pelanggan. Penelitian ini juga menunjukkan bahwa kepercayaan elektronik menghasilkan $e$ loyalty. Hipotesis dalam penelitian ini adalah sebagai berikut:

$H_{3}:$ Kepercayaan berpengaruh positif dan signifikan terhadap loyalitas pengguna internet banking.

Thaichon et al. (2014 menyatakan bahwa dalam konteks e-banking, pemrosesan transaksi dan halaman web yang cepat dan secara teratur diperbarui dan isi yang ringkas di situs web e-banking akan meningkatka kepercayaan. Selain itu, gaya presentasi situs web juga mampu meningkatkan kepercayaan pelanggan terhadap penyedia $e$-banking sehingga pelanggan akan menjadi lebih loyal. Penelitian Shankar \& Jebarajakirthy (2019) menunjukkan kepercayaan memediasi hubungan antara keandalan dan loyalitas menggunakan internet banking. Dukungan dan layanan internet banking terhadap pelanggan tidak memiliki efek langsung pada loyalitas, efek itu melalui kepercayaan.

Penelitian Bhat et al. (2018) mengeksplorasi bagaimana peran customer knowledge management (CKM) dan kepuasan sebagai anteseden pelanggan yang percaya pada sektor perbankan. Penelitian ini mengungkapkan bahwa CKM dan kepuasan berdampak positif bagi kepercayaan pelanggan dan kepercayaan pelanggan memiliki dampak signifikan terhadap loyalitas. Hipotesis dalam penelitian ini adalah sebagai berikut:

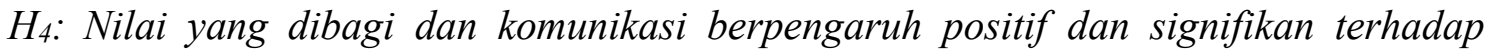
loyalitas dengan pemediasi kepercayaan.

\section{Metodologi Penelitian}

Penelitian ini merupakan penelitian empiris yaitu studi tentang fakta-fakta yang dilakukan berdasarkan observasi dan pengamatan. Pengambilan sampel menggunakan non probability sampling dengan teknik purposive sampling. Karakteristik sampel yang digunakan dalam penelitian ini adalah responden yang memiliki rekening koran dan mengetahui layanan internet banking yang disediakan. Selain itu, responden juga pernah melakukan transaksi perbankan melalui internet baik internet banking atau mobile banking, dalam hal ini jangka waktu yang ditetapkan adalah 1 bulan terakhir.

Peneliti melakukan survei dengan cara menyebarkan daftar pernyataan terstruktur berupa kuesioner kepada responden. Analisis data dilakukan dengan metode analisis jalur. Analisis jalur merupakan perluasan dari analisis linier berganda, atau analisis jalur adalah menggunakan analisis regresi untuk menaksir hubungan kausalitas antar variabel (model casual) yang telah ditetapkan sebelumnya berdasarkan teori (Ghozali, 2018).

Penelitian ini menggunakan beberapa indikator yang dikembangkan oleh penelitian sebelumnya. Indikator masing-masing variabel diikuti oleh pertanyaan yang sudah disesuaikan dengan kondisi di lapangan. 
Tabel 1. Instrumen Penelitian

\begin{tabular}{|c|c|c|}
\hline Variabel & Indikator & Pernyataan \\
\hline \multirow[t]{3}{*}{ Nilai yg dibagi } & Privasi & $\begin{array}{l}\text { 1. Menurut saya menggunakan Internet banking data pribadi saya } \\
\text { terjaga kerahasiaannya. } \\
\text { 2. Saya menggunakan internet banking dimanapun. } \\
\text { 3. Internet banking memahami kebutuhan saya. } \\
\text { 4. Internet banking sesuai dengan yang saya inginkan. }\end{array}$ \\
\hline & Keamanan & $\begin{array}{l}\text { 5. Internet banking terjamin keamanannya. } \\
\text { 6. Selama menggunakan Internet banking saya tidak pernah } \\
\text { mengalami pembobolan. } \\
\text { 7. Internet banking yang saya gunakan akurat dan tepat dalam } \\
\text { bertransaksi. }\end{array}$ \\
\hline & Etika & $\begin{array}{l}\text { 8. Bagi saya, tidaklah sulit menggunakan internet banking. } \\
\text { 9. Menurut saya, menggunakan internet banking tidak melanggar } \\
\text { norma agama. } \\
\text { 10. Menurut saya, menggunakan internet banking sudah menjadi } \\
\text { kebiasaan masyarakat. }\end{array}$ \\
\hline \multirow[t]{3}{*}{ Komunikasi } & Keterbukaan & $\begin{array}{l}\text { 1. Informasi terbaru saya dapatkan saat menggunakan internet } \\
\text { banking. } \\
\text { 2. Internet banking dapat menjelaskan tentang semua produk yang } \\
\text { ditawarkan. } \\
\text { 3. Saya menggunakan internet banking yang dapat digunakan oleh } \\
\text { seluruh nasabahnya. }\end{array}$ \\
\hline & $\begin{array}{l}\text { Kecepatan } \\
\text { Respon }\end{array}$ & $\begin{array}{l}\text { 4. Layanan internet banking yang saya gunakan cepat. } \\
\text { 5. Layanan internet banking yang saya gunakan dapat digunakan } \\
\text { untuk memasukan kritik dan saran. } \\
\text { 6. Layanan internet banking yang saya gunakan dapat dengan cepat } \\
\text { menyelesaikan permasalahan. }\end{array}$ \\
\hline & $\begin{array}{l}\text { Kualitas } \\
\text { Informasi }\end{array}$ & $\begin{array}{l}\text { 7. Layanan internet banking yang saya gunakan sesuai dengan } \\
\text { kebutuhan. } \\
\text { 8. Apa yang disampaikan melalui internet banking sangat berharga } \\
\text { bagi konsumen. } \\
\text { 9. Informasi yang disampaikan melalui internet banking dapat } \\
\text { diandalkan. } \\
\text { 10. Internet banking terdapat bukti yang meyakinkan pada setiap } \\
\text { informasi. }\end{array}$ \\
\hline \multirow[t]{3}{*}{ Kepercayaan } & $\begin{array}{l}\text { Orientasi } \\
\text { Teknologi }\end{array}$ & $\begin{array}{l}\text { 1. Saya percaya dengan keamanan teknologi sistem online pada } \\
\text { internet banking yang saya gunakan. } \\
\text { 2. Saya percaya teknologi internet banking yang saya gunakan } \\
\text { dapat memudahkan transaksi. } \\
\text { 3. Saya percaya teknologi internet banking yang saya gunakan } \\
\text { dapat dipertanggungjawabkan. }\end{array}$ \\
\hline & Reputasi & $\begin{array}{l}\text { 4. Saya percaya dengan reputasi internet banking yang saya } \\
\text { gunakan. } \\
\text { 5. Saya percaya dengan kualitas internet banking yang saya } \\
\text { gunakan. } \\
\text { 6. Saya percaya layanan internet banking yang saya gunakan sesuai } \\
\text { dengan kebutuhan saya. }\end{array}$ \\
\hline & $\begin{array}{l}\text { Resiko yang } \\
\text { Dirasakan }\end{array}$ & $\begin{array}{l}\text { 7. Kecil kemungkinan terjadi kecurangan bertransaksi } \\
\text { menggunakan internet banking yang saya gunakan. } \\
\text { 8. Saya percaya internet banking yang saya gunakan aman. } \\
\text { 9. Saya percaya tingkat akurasi internet banking yang saya } \\
\text { gunakan. } \\
\text { 10. Menggunakan internet banking tidak beresiko kesalahan } \\
\text { pencatatan }\end{array}$ \\
\hline
\end{tabular}

Sumber: Mukherjee \& Prithwiraj (2003) 
Tabel 1. Instrumen Penelitian (lanjutan)

\begin{tabular}{|c|c|c|}
\hline Variabel & Indikator & Pernyataan \\
\hline \multirow[t]{2}{*}{ Loyalitas } & Minat & $\begin{array}{l}\text { 1. Saya menggunakan internet banking untuk kemudahan } \\
\text { bertransaksi. } \\
\text { 2. Saya terus setia menggunakan internet banking karena bisa dibuka } \\
\text { dalam jangka waktu } 24 \text { jam sehari. } \\
\text { 3. Saya merekomendasikan kepada orang lain untuk menggunakan } \\
\text { layanan internet banking. } \\
\text { 4. Saya secara berkelanjutan menggunakan layanan internet } \\
\text { banking. }\end{array}$ \\
\hline & Komitmen & $\begin{array}{l}\text { 5. Saya tidak tertarik menggunakan layanan lain selain internet } \\
\text { banking. } \\
\text { 6. Saya memberikan informasi tentang keunggulan layanan internet } \\
\text { banking kepada orang terdekat saya. } \\
\text { 7. Saya mengutamakan menggunakan layanan internet banking } \\
\text { dalam bertransaksi. } \\
\text { 8. Saya yakin bahwa internet banking merupakan layanan secara } \\
\text { online yang baik untuk saya. }\end{array}$ \\
\hline
\end{tabular}

Sumber: Mukherjee \& Prithwiraj (2003)

\section{Hasil Penelitian}

Selama masa pengumpulan data peneliti membagikan kuesioner yang akan diisi oleh para responden. Setelah 100 kuesioner dikumpulkan maka dilakukan pemeriksaan kelengkapan jawaban yang diberikan oleh responden. Sekaran \& Bougie (2017) mengusulkan aturan untuk menentukan ukuran sampel yaitu ukuran sampel lebih dari 30 dan kurang dari 500 adalah tepat untuk kebanyakan penelitian.

Berdasarkan pertimbangan bahwa penelitian ini adalah bersifat exploratory maka penulis menggunakan metode PLS (Parsial Least Square). Evaluasi model dalam PLS akan melewati dua tahapan yaitu evaluasi model pengukuran dan evaluasi model struktural. Evaluasi model pengukuran atau outer model dilakukan untuk menilai reliabilitas dan validitas dari indikator-indikator pembentuk konstruk laten. Sedangkan evaluasi model struktural atau inner model bertujuan untuk memprediksi hubungan antar variabel laten dengan melihat seberapa besar variance yang dapat dijelaskan dan untuk mengetahui signifikansi dan P-value (Ghozali, 2018).

\subsection{Data Deskriptif}

Berikut ini disampaikan deskripsi data dari responden yang digunakan dalam penelitian ini.

Tabel 2: Jenis kelamin responden

\begin{tabular}{llcc}
\hline & Jenis Kelamin & Jumlah & Persen \\
\hline Jenis kelamin & Laki-Laki & 43 & $43 \%$ \\
& Perempuan & 57 & $57 \%$ \\
\hline Pekerjaan & Karyawan Swasta & 32 & $32 \%$ \\
& Pegawai Negeri & 43 & $43 \%$ \\
& Wirausaha & 25 & $25 \%$ \\
\hline Usia & $17-21$ Tahun & 13 & $13 \%$ \\
& $22-27$ Tahun & 62 & $62 \%$ \\
& Lebih dari 27 Tahun & 25 & $25 \%$ \\
\hline
\end{tabular}




\subsection{Evaluasi Model Pengukuran (outer model)}

Evaluasi model pengukuran dimulai dengan melihat indikator reliability yaitu besarnya variance dari indikator untuk menjelaskan konstruk laten. Menurut Ghozali (2018) composite reliability digunakan untuk melihat reliabilitas konstruk yaitu harus $>0,7$. Convergent validity menggunakan indikator reflektif dapat dilihat dari nilai korelasi antara skor item/indikator dengan skor konstruknya. Indikator dianggap reliable bila nilai korelasi diatas 0,7 namun pada riset tahap pengembangan nilai 0,5 sampai 0,6 masih dapat diterima.

Tabel 3. Outer Loadings

\begin{tabular}{|c|c|c|c|c|c|}
\hline & & $\begin{array}{l}\text { Outer } \\
\text { Loadings }\end{array}$ & $\begin{array}{l}\text { Composite } \\
\text { Reliability }\end{array}$ & $\begin{array}{l}\text { Average Variance } \\
\text { Extracted (Ave) }\end{array}$ & $\begin{array}{l}\text { Cronbach's } \\
\text { Alpha }\end{array}$ \\
\hline \multirow[t]{6}{*}{ Komunikasi } & CM1 & 0,701 & 0,783 & 0,379 & 0,788 \\
\hline & CM10 & 0,723 & & & \\
\hline & $\mathrm{CM} 2$ & 0,532 & & & \\
\hline & $\mathrm{CM} 4$ & 0,546 & & & \\
\hline & CM6 & 0,606 & & & \\
\hline & CM9 & 0,561 & & & \\
\hline \multirow[t]{10}{*}{ Kepercayaan } & K1 & 0,660 & 0,893 & 0,457 & 0,893 \\
\hline & K10 & 0,778 & & & \\
\hline & K2 & 0,742 & & & \\
\hline & K3 & 0,618 & & & \\
\hline & K4 & 0,688 & & & \\
\hline & K5 & 0,575 & & & \\
\hline & K6 & 0,548 & & & \\
\hline & K7 & 0,685 & & & \\
\hline & K8 & 0,745 & & & \\
\hline & K9 & 0,685 & & & \\
\hline \multirow[t]{8}{*}{ Loyalitas } & LY1 & 0,707 & 0,828 & 0,379 & 0,827 \\
\hline & LY2 & 0,701 & & & \\
\hline & LY3 & 0,617 & & & \\
\hline & LY4 & 0,537 & & & \\
\hline & LY5 & 0,601 & & & \\
\hline & LY6 & 0,680 & & & \\
\hline & LY7 & 0,519 & & & \\
\hline & LY8 & 0,523 & & & \\
\hline Nilai yang & SV1 & 0,691 & 0,929 & 0,570 & 0,931 \\
\hline \multirow[t]{9}{*}{ Dibagi } & SV10 & 0,606 & & & \\
\hline & SV2 & 0,850 & & & \\
\hline & SV3 & 0,802 & & & \\
\hline & SV4 & 0,919 & & & \\
\hline & SV5 & 0,628 & & & \\
\hline & SV6 & 0,783 & & & \\
\hline & SV7 & 0,645 & & & \\
\hline & SV8 & 0,715 & & & \\
\hline & SV9 & 0,843 & & & \\
\hline
\end{tabular}


Tabel 4. Cross Loading

\begin{tabular}{lcccc}
\hline & Kepercayaan & Komunikasi & Loyalitas & Nilai Yang Dibagi \\
\hline CM1 & 0,499 & $\mathbf{0 , 7 0 1}$ & 0,481 & 0,477 \\
CM10 & 0,500 & $\mathbf{0 , 7 2 3}$ & 0,511 & 0,445 \\
CM2 & 0,380 & $\mathbf{0 , 5 3 2}$ & 0,362 & 0,373 \\
CM4 & 0,373 & $\mathbf{0 , 5 4 6}$ & 0,390 & 0,486 \\
CM6 & 0,412 & $\mathbf{0 , 6 0 6}$ & 0,437 & 0,511 \\
CM9 & 0,407 & $\mathbf{0 , 5 6 1}$ & 0,377 & 0,454 \\
\hline K1 & $\mathbf{0 , 6 6 0}$ & 0,556 & 0,611 & 0,415 \\
K10 & $\mathbf{0 , 7 7 8}$ & 0,610 & 0,740 & 0,490 \\
K2 & $\mathbf{0 , 7 4 2}$ & 0,557 & 0,737 & 0,417 \\
K3 & $\mathbf{0 , 6 1 8}$ & 0,300 & 0,677 & 0,366 \\
K4 & $\mathbf{0 , 6 8 8}$ & 0,454 & 0,659 & 0,515 \\
K5 & $\mathbf{0 , 5 7 5}$ & 0,453 & 0,551 & 0,351 \\
K6 & $\mathbf{0 , 5 4 8}$ & 0,276 & 0,589 & 0,344 \\
K7 & $\mathbf{0 , 6 8 5}$ & 0,505 & 0,669 & 0,422 \\
K8 & $\mathbf{0 , 7 4 5}$ & 0,474 & 0,777 & 0,418 \\
K9 & $\mathbf{0 , 6 8 5}$ & 0,495 & 0,672 & 0,426 \\
\hline LY1 & 0,692 & 0,569 & $\mathbf{0 , 7 0 7}$ & 0,489 \\
LY2 & 0,697 & 0,499 & $\mathbf{0 , 7 0 1}$ & 0,397 \\
LY3 & 0,612 & 0,447 & $\mathbf{0 , 6 1 7}$ & 0,363 \\
LY4 & 0,532 & 0,346 & $\mathbf{0 , 5 3 7}$ & 0,368 \\
LY5 & 0,610 & 0,261 & $\mathbf{0 , 6 0 1}$ & 0,364 \\
LY6 & 0,672 & 0,468 & $\mathbf{0 , 6 8 0}$ & 0,466 \\
LY7 & 0,519 & 0,389 & $\mathbf{0 , 5 1 9}$ & 0,208 \\
LY8 & 0,514 & 0,425 & $\mathbf{0 , 5 2 3}$ & 0,301 \\
\hline SV1 & 0,451 & 0,435 & 0,395 & $\mathbf{0 , 6 9 1}$ \\
SV10 & 0,367 & 0,506 & 0,379 & $\mathbf{0 , 6 0 6}$ \\
SV2 & 0,542 & 0,610 & 0,501 & $\mathbf{0 , 8 5 0}$ \\
SV3 & 0,475 & 0,571 & 0,513 & $\mathbf{0 , 8 0 2}$ \\
SV4 & 0,589 & 0,564 & 0,539 & $\mathbf{0 , 9 1 9}$ \\
SV5 & 0,384 & 0,604 & 0,388 & $\mathbf{0 , 6 2 8}$ \\
SV6 & 0,488 & 0,606 & 0,473 & $\mathbf{0 , 7 8 3}$ \\
SV7 & 0,397 & 0,555 & 0,396 & $\mathbf{0 , 6 4 5}$ \\
SV8 & 0,424 & 0,627 & 0,456 & 0,528 \\
SV9 & 0,508 & 0,540 & 0,5 & \\
\hline & & & & \\
\hline
\end{tabular}

Berdasarkan tabel 3 dapat dilihat bahwa nilai outer loading berada di atas 0,5 kecuali untuk penyataan CM3,CM5, CM7 dan CM8 maka ketiga penyataan tersebut dikatakan tidak valid. Cara lain untuk melihat discriminant validity dengan membandingkan akar kuadrat dari average variance extracted untuk tiap konstruk dengan konstruk lainnya dalam model. Berdasarkan kedua cara tersebut kita dapat menemukan pernyataan-pernyataan valid yang data responnya dapat digunakan untuk analisis selanjutnya. 
Tabel 5. Fornell Larcker Criterium

\begin{tabular}{lllll}
\hline & Kepercayaan & Komunikasi & Loyalitas & Nilai Yang Dibagi \\
\hline Kepercayaan & 0,676 & & & \\
Komunikasi & 0,701 & 0,616 & & \\
Loyalitas & 0,992 & 0,698 & 0,615 & \\
Nilai yang Dibagi & 0,619 & 0,740 & 0,610 & 0,755 \\
\hline
\end{tabular}

Disamping uji validitas konstruk, dilakukan juga uji reliabilitas konstruk yang diukur dengan menggunakan dua kriteria yaitu composite reliability dan cronbach alpha dari blok indikator yang mengukur konstruk. Kontruk dinyatakan reliabel jika nilai composite reliability maupun cronback alpha di atas 0.70 . Berdasarkan tabel 5 dapat menyatakan bahwa konstruk yang digunakan dalam penelitian ini adalah reliabel.

\subsection{Evaluasi Model Struktural (inner model)}

Tabel 6. Evaluasi Model Struktural

\begin{tabular}{lccc}
\hline & Original Sample & T Statistics & P Values \\
\hline Nilai Yang Dibagi $\rightarrow$ Kepercayaan & 0,321 & 2,566 & $0,011^{*}$ \\
Komunikasi $\rightarrow$ Kepercayaan & 0,386 & 3,555 & $0,000^{* *}$ \\
Kepercayaan $\rightarrow$ Loyalitas & 0,791 & 13,520 & $0,000^{* *}$ \\
Nilai Yang Dibagi $\rightarrow$ Loyalitas & 0,045 & 0,610 & 0,542 \\
Komunikasi $\rightarrow$ Loyalitas & 0,072 & 0,882 & 0,378 \\
\hline
\end{tabular}

Keterangan: $* * \operatorname{sig}<1 \%, * \operatorname{sig}<5 \%$

Tabel 6 menjelaskan bahwa pengujian pengaruh nilai yang dibagi dan komunikasi terhadap kepercayaan diperoleh $\mathrm{p}$ value $<0,05\left(\mathrm{H}_{1}\right.$ dan $\mathrm{H}_{2}$ terbukti). Selain itu signifikansi pengaruh kepercayaan terhadap loyalitas adalah $<0,05\left(\mathrm{H}_{3}\right.$ terbukti). Selanjutnya berdasarkan tabel 6, untuk membuktikan kepercayaan sebagai variabel mediasi dapat dilihat dari nilai koefisien pengaruh langsung dan tidak langsung antara komunikasi dan nilai yang dibagi terhadap loyalitas. Nilai koefisien pengaruh langsung antara komunikasi terhadap loyalitas adalah sebesar 0,072 . Nilai koefisien pengaruh tidak langsung komunikasi terhadap loyalitas melalui kepercayaan sebesar 0,3014 (0.386 X 0,791). Nilai koefisien pengaruh langsung antara nilai yang dibagi terhadap loyalitas adalah 0,045 . Nilai koefisien pengaruh tidak lansung nilai yang dibagi terhadap loyalitas melalui kepercayaan sebesar $0,2539(0,321$ $\mathrm{X}$ 0,791). Berdasarkan perbandingan diperoleh bahwa nilai koefisien pengaruh tidak langsung lebih besar dibandingkan nilai koefisien pengaruh langsung, maka dapat dikatakan bahwa nilai yang dibagi dan komunikasi mempengaruhi loyalitas dengan pemediasi kepercayaan $\left(\mathrm{H}_{4}\right.$ terbukti).

\section{Pembahasan dan Implikasi}

Berdasarkan hasil analisa data terbukti bahwa komunikasi atau informasi yang disampaikan berkaitan dengan internet banking memiliki pengaruh yang signifikan terhadap kepercayaan. Hal ini sejalan dengan penelitian yang dilakukan oleh Maadi et al. (2016) yang menyatakan bahwa informasi terinci yang disampaikan perusahaan memiliki dampak untuk membangun kepercayaan. Bhat et al. (2018) juga mengemukakan bahwa pengetahuan dari pelanggan seharusnya dapat dibagikan kepada pelanggan lain guna meningkatkan kepercayaan atas 
layanan internet banking. Pengaruh kepercayaan terhadap loyalitas terbukti memiliki pengaruh yang signifikan. Loyalitas merupakan bentuk kesediaan seorang pelanggan untuk tetap berkomitmen dalam menggunakan layanan internet banking. Munculnya kesediaan dalam menggunakan layanan internet banking berasal dari adanya kepercayaan atas aplikasi tersebut. Pengalaman dalam menggunakan, manfaat yang dirasakan oleh nasabah dalam menggunakan aplikasi internet banking dan rendahnya resiko yang dirasakan akan meningkatkan kepercayaan nasabah atas internet banking yang berdampak pada makin meningkatnya loyalitas nasabah atas internet banking. Quach et al. (2016) juga menunjukkan bahwa nasabah akan menjadi lebih percaya atas layanan internet banking saat bank mampu memberikan informasi untuk solusi atas permasalahan yang dihadapi nasabah. Chung et al. (2016) juga menggambarkan bahwa komunikasi dua arah yang dilakukan melalui sebuah situs web akan meningkatkan kepercayaan.

Penelitian ini juga membuktikan bahwa nilai yang dibagi memiliki pengaruh yang signifikan terhadap kepercayaan. Hal ini sejalan dengan penelitian yang dilakukan oleh Arcand et al. (2017) yang menyatakan bahwa dimensi hedonis yaitu kesenangan dan faktor sosial memiliki pengaruh terhadap kepercayaan. Dalam faktor sosial, bagaimana sebuah pengalaman itu dibagikan antara satu orang dengan orang yang lain dapat menimbulkan kepercayaan atas suatu layanan atau produk tertentu. Kucukemiroglu \& Kara (2015) menyatakan bahwa pembicaraan yang dilakukan di media sosial dapat meningkatkan opini seseorang terhadap sebuah objek, terlebih lagi pembicaraan itu dilakukan oleh orang-orang yang berada dalam daftar pertemanan.

Peran kepercayaan sebagai variabel mediasi antara nilai yang dibagi dan komunikasi terhadap loyalitas terbukti secara signifikan dalam penelitian ini. Informasi yang di berikan dalam hal ini adalah wujud komunikasi aplikasi internet banking dan kesediaan nasabah untuk membagikan pengalamannya dalam menggunakan aplikasi internet banking terbukti memiliki pengaruh yang signifikan terhadap kepercayaan dalam artian akan menurunkan tingkat resiko yang dirasakan oleh nasabah, hal inilah yang akan menguatkan loyalitas nasabah. Hasil ini sejalan dengan penelitian yang dilakukan oleh Chou et al. (2015) yang menyatakan bahwa sebuah situs web yang mampu didesain berbeda dengan situs yang lain dan lebih informatif akan meningkatkan kepercayaan penggunanya dan selanjutnya akan mempengaruhi loyalitas penggunanya. Cao et al. (2018) juga menyatakan bahwa peran mediasi dari kepercayaan akan ada saat seorang pengguna mobile payment merasakan kepuasan yang akan berdampak pada kesediaan untuk terus menggunakan aplikasi mobile payment. Bhat et al. (2018) peran mediasi kepercayaan pelanggan dalam pengetahuanloyalitas dan kepuasan-hubungan loyalitas juga dieksplorasi. Temuan dalam penelitian ini mengungkapkan bahwa CKM dan kepuasan berdampak positif bagi kepercayaan pelanggan dan kepercayaan pelanggan memiliki dampak signifikan terhadap loyalitas.

\section{Kesimpulan, Keterbatasan dan Saran}

Hasil penelitian membuktikan bahwa nilai yang dibagi dan komunikasi berpengaruh terhadap kepercayaan dan kepercayaan berpengaruh terhadap loyalitas. Selain itu kepercayaan memediasi hubungan antara nilai yang dibagi dan komunikasi dengan loyalitas. 
Penelitian terbatas dimana penggunaan internet banking tidak membedakan antara nasabah yang mengakses dengan menggunakan perangkat komputer atau smartphone. Komunikasi yang disampaikan dengan menggunakan perangkat smartphone tentunya tidak sekaya informasi yang disampaikan melalui web. Penelitian ini hanya melihat nilai yang dibagi adalah hanya dari privacy, keamanan dan etika penelitian berikutnya mungkin juga dapat melihat segi manfaat yang dirasakan, kemudahan yang dirasakan.

\section{Daftar Pustaka}

Amin, M. (2016). Internet banking service quality and its implication on e-customer satisfaction and e-customer loyalty. International Journal of Bank Marketing, 34(3), 280-306.

Arcand, M., PromTep, S., Isabelle, B., \& Lova, R. (2017). Mobile banking service quality and customer relationships. International Journal of Bank Marketing, 35(7), 10681089.

Barnes, J. G. (2003). Secrets Of Customer Relationship Management, ANDI. Yogyakarta.

Bhat, S. A., Darzi, M. A., \& Parrey, S. H., (2018). Antecedents of customer loyalty in Banking Sector: A Mediational Study. The Journal for Decision Makers, 43(2), 92105.

Cao, X., Yu, L., Liu, Z., Gong, M., \& Adeel, L. (2015). Understanding mobile payment users' continuance intention: A trust transfer perspective. Internet Research, 28(2), 456-476.

Chung, C.-C., Chao, L.-C., Chen, C.-H., \& Lou, S.-J. (2016). Evaluation of interactive website design indicators for e-entrepreneurship. Sustainability, 8(4), 1-21.

Chou, S., Chen, C-W., \& Lin, J-Y. (2015). Female online shoppers examining the mediating roles of e-satisfaction and e-trust on e-loyalty development. Internet Research, 25 (4), 542-561.

Daud, A., Farida, N., Andriyansah., \& Razak, M. (2018). Impact of customer trust toward loyalty: the mediating role of perceived usefulness and satisfaction. Journal of Business and Retail Management Research, 13(2).

Ghozali, I. (2018), Aplikasi Analisis Multivariate dengan program IBM SPSS 25, Badan Penerbit Universitas Diponegoro.

Kaabachi, S., Mrad, S. B., \& Fiedler, A. (2020). The moderating effect of e-bank structure on French consumers' trust. International Journal of Bank Marketing, 38(2), 501528.

Kaur, G., Sharma, R.D., \& Mahajan, N. (2012). Exploring customer switching intentions through relationship marketing paradigm. International Journal of Bank Marketing, 30(4), 280-302.

Khalfan, A., Yaqoub, S.Y., Al-Refaei, Y., \& Al-Hajery, M. (2006). Factors influencing the adoption of internet banking in Oman: A descriptive case study analysis. International Journal of Financial Services Management, 1(2), 155-172.

Kuncoro, M. (2013). Metode Riset untuk Bisnis dan Ekonomi, Edisi 4. Jakarta; Erlangga.

Kucukemiroglu, S., \& Kara, A. (2015). Online word-of-mouth communication on social networking sites: An empirical study of Facebook users. International Journal of Commerce and Management, 25(1), 2-20.

Lovelock, C.H., \& Wright, L.K. (1999). Manajemen Pemasaran Jasa, Indeks. Jakarta.

Maadi, M., Maadi, M., \& Javidnia, M. (2016). Identification of factors influencing building initial trust in e-commerce. Iranian Journal of Management Studies, 9(3), 483-503. 
Mann, B. J. S., \& Sahni, S. K. (2011). Inter-relationship of website interactivity and customer outcomes: Building trust in the internet banking website. Global Business Review, 12(1), 99-115.

Monroe, K. B. (1990). Pricing: Making profitable Decisions. 2nd Edition, Singapore: McGraw-Hill.

Morgan, R. M., \& Shelby, D. (1994). The commitment trust theory of relationship marketing. Journal of Marketing, 58(3), 20-38.

Mowen, J. C., \& Minor, M. (2002). Perilaku Konsumen. Edisi Kelima, Jilid 1. Edisi Bahasa Indonesia. Terjemahan Lina Salim. PT Penerbit Erlangga, Jakarta.

Mukherjee, A., \& Prithwiraj, N. (2003). A model of trust in online relationship banking. International Journal of Bank Marketing, 21(1), 5-15.

Nilashi, M., Jannach, D., Ibrahim, O. B., Ahmadi, H. \& Esfahani, M. D. (2016) Recommendation quality, transparency, and website quality for trust-building in recommendation agents. Electronic Commerce Research and Applications, 19, 7084.

Punyatoya, P. (2019) Effects of cognitive and affective trust on online customer behavior. Marketing Intelligence \& Planning, 37(1), 80-96.

Quach, T.N., Thaichon, P. \& Jebarajakirthy, C. (2016). Internet service providers' service quality and its effect on customer loyalty of different usage patterns. Journal of Retailing and Consumer Services. 29(2), 104-113.

Sekaran, U., \& Bougie. R. (2017). Metode Penelitian untuk Bisnis. Salemba Empat

Shankar, A., \& Jebarajakirthy, C. (2019). The influence of e-banking service quality on customer loyalty: A moderated mediation approach. International Journal of Bank Marketing, 37(5), 1119-1142.

Thaichon, P., Lobo, A., Prentice, C., \& Quach, T.N. (2014). The development of service quality dimensions for internet service providers: Retaining customers of different usage patterns. Journal of Retailing and Consumer Services, 21(6), 1047-1058.

Tjiptono, F., \& Gregorius, C. (2005). Service, Quality and Satisfaction. Edisi Pertama, Penerbit Andi. Yogyakarta.

Toufaily, E., Souiden, N., \& Ladhari, R. (2013). Customer trust toward retail websites: comparison between pure click and click-and-brick retailers. Journal of Retailing and Consumer Services, 42, 37-46.

Vinayek, R., \& Jindal, P. (2011). An empirical investigation of key antecedents of customer preference of internet banking in Indian context. Asia-Pacific Business Review, 7(3), 63-71. 